\title{
The Responsibilities of Influencers in Promoting Tie-Dye Motif Products Based on Copyright Law
}

\section{${ }^{\Omega}$ Putri Triari Dwijayanthi ${ }^{1}$, Ni Ketut Supasti Dharmawan ${ }^{1}$}

${ }^{1}$ Faculty of Law, Universitas Udayana, Indonesia

\author{
^email: putritriari@gmail.com
}

\begin{abstract}
Tie-dye is known as a method of dyeing which results in a design on the fabric by which the fabric is collected and tied tightly with fibers, rope, or yarn, then dyed or colored. The cloth is then processed into clothes, masks, and other accessories which can now be easily found in several online shops. This paper aims to identify, analyze, and elaborate on the legal protection of tie-dye motifs based on Indonesia Law Number 28 the Year 2014 concerning Copyright and the responsibilities of influencers who promote tie-dyed motif products. This is normative legal research with a statutory approach and a conceptual approach. The technique of tracing legal materials uses document study techniques and the analysis of studies uses qualitative analysis. The study shows that the tie-dye motif has been protected under Copyright law both nationally and internationally. Tie-dye motif as a form of continues to be developed with a high economic value has received clear protection under Indonesia Law Number 28 of 2014 concerning Copyright. The clear arrangement of tie-dyes is becoming increasingly important, especially when tie-dyes are used commercially. Regarding the Announcement of a copyrighted work, such as tie-dye products, the element of the uniqueness of form and originality are important points in copyright protection, so it is only natural for an influencer not to allow the sale and/or duplication of goods resulting from infringement of copyright and/or Related Right as regulated in Indonesia Copyright Law.
\end{abstract}

Keywords: Tie-dye; Legal Protection; Copyright

Date of Submission: September 01, 2020

Date of Publication: November 05, 2020

DOI: http://dx.doi.org/10.33096/substantivejustice.v3i2.90

\section{INTRODUCTION}

Tie-dye is a technique for making motifs on fabrics that has been known for a long time in various parts of the world by utilizing a barrier such as a rope or thread in the formation of its motif. The introduction and use of the tie-dye technique in itself is nothing new in the world of fashion. The use of bright colors and handmade patterns in the tiedye technique is unique for fashion lovers. The tie-dye technique for dyeing the fabric involves a unique blend of colors by folding, twisting, or tying the fabric. As one of the 
handmade works, the tie-dye results will not always be the same as one another, ${ }^{1}$ although there is the possibility of partial similarity, especially from the composition of global colors and shapes, such as rainbow shapes, lines, or circles.

Simply put, the term tie-dye is known as 'teknik ikat celup'. ${ }^{23}$ The tie-dye trend itself has been known from 1954 to 1975, namely during the Vietnam War. At that time, tie-dye was used by young Americans as a form of rebellion against conservative dress codes and appearance. ${ }^{4}$ In San Francisco, America, the tie-dye trend also developed around the 1970s, namely the Summer of Love era. ${ }^{5}$ In Indonesia, the tie-dye technique is also known as tritik jumputan (in Java) and sasirangan (in Banjarmasin). ${ }^{6}$ Tritik jumputan itself is a handicraft product in Java that uses fabric media and a barrier material such as rope or thread to make a pattern which is then dyed in the dye. ${ }^{7}$

Internationally, the tie-dye technique has again become a trend since 2019, when one of the well-known brands, Dior, launched the Spring 2019 collection. ${ }^{8}$ Besides Dior, several well-known brands, such as Adidas and BAPE, have also introduced updates to the tie-dye trend in their clothing collections. At present, the tie-dye trend is also being cultivated by several local brands in Indonesia. Clothes with tie-dye motifs can now be easily found in several online shops on social media such as Instagram. Apart from clothes, various accessories such as masks, scrunchies (hair ties), bandanas, scarves, tote bags, and even interior elements such as pillowcases are also made using tie-dye fabrics. Clothing and various accessories made with the tie-dye technique are becoming popular because many influencers on social media, especially Instagram, use and even promote several local brands that sell products with tie-dye motifs.

In the world of entrepreneurship, the ATM method is known, which stands for Amati (observe), Tiru (copy), and Modifikasi (modify). ${ }^{9}$ Referring to this method, in the process of making a product, a person can use or re-express information or an idea that

\footnotetext{
1 Nakamura, R., Tanaka, Y., Ogata, A., \& Masakazu, N. (2014). Scientific evidence by fluorescence spectrometry for safflower red on ancient Japanese textiles stored in the Shosoin Treasure House repository. Studies in Conservation, 59(6), p. 368.

${ }_{2}$ Widodo, S. T. (2012). Kriya Tekstil Tie-Dye (lkat Celup): Sebuah Media Eksplorasi Estetis Yang Populer. Corak: Jurnal Seni Kriya, 1(2), p. 101.

${ }^{3}$ Halls, J., \& Martino, A. (2018). Cloth, copyright, and cultural exchange: textile designs for export to Africa at the National Archives of the UK. Journal of Design History, 31(3), p. 237.

${ }^{4}$ Dianawati, V. (2019). Fimela Historia: Seni Tekstil Tie-Dye yang Diprediksi Jadi Tren di Tahun 2020. Retrieved from https://www.fimela.com/beauty-health/read/3862121/fimela-historia-seni-tekstil-tie-dye-yangdiprediksi-jadi-tren-di-tahun-2019, accessed on August 7, 2020.

${ }^{5}$ Ramadhania, N. (2018). Tie-Dye Peluang Bisnis Baru melalui Tren Fashion 2018. Retrieved from: https://www.kompasiana.com/nurramadhania1456/5b115451dd0fa852d10566a2/tie-dye-peluang-bisnis-barumelalui-tren-fashion-2018?page=all, accessed on August 7, 2020.

6 Ristiani, S. (2016). Pengembangan Teknik Tritik Jumputan Dengan Sistem Lipat lkat Dan Lipat Jelujur. Dinamika Kerajinan Dan Batik, 33(1), p. 9-24. Doi: http://dx.doi.org/10.22322/dkb.v33i1.1102.

7 Ibid.

8 Warman, S. (2020). 6 Brand Lokal Keluarkan Motif Tie Dye Untuk Tampil Stylish. Retrieved from: https://www.herworld.co.id/Article/2020/7/14657-6-brand-lokal-keluarkan-motif-tie-dye-untuk-tampil-stylish, accessed on August 7, 2020.

9 Haryanto, H. (2020). Penerapan Transformasi Perpustakaan Berbasis Inklusi Sosial Di Perguruan Tinggi Melalui Literasi Kewirausahaan Dan Entrepreneur Corner: Studi Pada Perpustakaan Universitas Sebelas Maret. Jurnal Ipi (Ikatan Pustakawan Indonesia), 5(1), pp. 217-224. https://doi.org/10.1234/jurnal ipi.v5i1.49
} 
has been protected into a new work or creation as long as the idea is expressed differently. ${ }^{10}$ However, it is not uncommon for several online shops to sell items with tiedye motifs and colors similar to different brands without any modification to the product being sold itself.

Based on the background described above, it is important to examine legal issues regarding the similarity of tie-dye motifs from a copyright perspective, and what is the responsibility of an influencer who promotes products with tie-dye motifs that have similar motives but with different brands.

This research, when compared with several previous studies, has similarities in terms of topics, namely both studying tie-dye motifs, but the focus of the study is different. This paper emphasizes the protection of tie-dye motifs from a copyright perspective as well as the responsibility of an influencer who promotes products with tie-dye motifs that have similar motifs with different brands. In other words, there is an indication of copyright infringement on a work.

Previous studies conducted by Asri Cahaya Mustika in 2018 examined Copyright Protection of the Buketan Batik Motif as Cultural Heritage in Pekalongan (Study of Pekalongan Traditional Batik Artwork). In this case, the focus of the researcher is the implementation of the law in providing Copyright protection for the Buketan Batik Motif as a Cultural Heritage in Pekalongan and the Implementation of Copyright protection for the Buketan Batik Motif as a cultural heritage in Pekalongan. ${ }^{11}$ Pande Nyoman Yori Pratana in 2017, also reviewed the Implementation of Legal Provisions on the Endek Fabric Motif Based on Law Number 28 of 2014 concerning Copyright in Gianyar Regency. In this case, the researcher's emphasis is on the implementation of the legal provisions on the Endek cloth motif in Gianyar Regency and the role of the government in enforcing the legal provisions on the Endek cloth motif copyright in Gianyar Regency. ${ }^{12}$

The purpose of this writing is to identify, analyze, and elaborate legal protection for tie-dye motif artwork based on Law Number 28 of 2014 concerning Copyright and the responsibilities of influencers who promote a product with a tie-dye motif. In order to achieve the purpose of writing, this paper will systematically discuss the relevant substance with the focus of the problem. First, it is presented about the legal protection of

${ }^{10}$ Mahartha, A. (2018). Pengalihwujudan Karya Sinematografi Menjadi Video Parodi Dengan Tujuan Komersial Perspektif Perlindungan HakCipta. Kertha Patrika, 40(01), pp. 13-23. Doi:10.24843/Kp2018.V40I01.P02

${ }_{11}$ Mustika, A. (2018). Perlindungan Hak Cipta atas Motif Batik Buketan sebagai Warisan Budaya di Pekalongan (Studi Terhadap Karya Seni Batik Tradisional Pekalongan). Notarius, 11(2), pp. 146-163. https://doi.org/10.14710/nts.v11i2.23460

12 Yori Pratana, P., Supasti Dharmawan, N., \& Sri Indrawati, A. (2017). Pelaksanaan Ketentuan Hukum Terhadap Motif Kain Endek Berdasarkan Undang-Undang Nomor 28 Tahun 2014 Tentang Hak Cipta Di Kabupaten Gianyar. Kertha Semaya: Journal IImu Hukum, Retrieved From https://ojs.unud.ac.id/index.php/kerthasemaya/Article/view/34985 
tie-dye artwork nationally and internationally. Second, the limit on the responsibility of an influencer in promoting a product, in this case, is a product that uses a tie-dye motif.

\section{METHOD}

The writing of this scientific paper is normative legal research. Normative legal research can be carried out by conducting studies on legal principles, legal systematics, research at the legal synchronization level, legal history and even carrying out legal comparisons. ${ }^{13}$ The same thing was also stated by Peter Mahmud Marzuki who views that legal research is a process to find answers to legal problems faced by examining legal rules, legal principles or legal doctrines. ${ }^{14}$ This paper is a normative legal research using a statute approach and a conceptual approach. Legal materials were traced with document study techniques and analyzed using qualitative analysis.

\section{ANALYSIS AND DISCUSSION}

\section{A. Concept and Protection of Tie-dye Motif based on Copyright Law}

An understanding of tie-dye can be traced through an encyclopedia. According to the Encyclopaedia of Britannica, tie-dye atau tie-dyeing is "a method of dyeing by hand in which colored patterns are produced in the fabric by gathering together many small portions of material and tying them with string before immersing the cloth in the dyebath". ${ }^{15}$ In the tie-dye technique, the dye cannot penetrate some parts of the fabric because there is a barrier in the form of a rope or thread that is tied in such a way to form unique patterns. After the dyeing process, the cloth that has been tied with thread or cloth can produce various unique shapes, such as circles, lines, or other patterns. Various shapes with unique hues can be produced after repeated dyeing or dyeing processes. ${ }^{16}$

"Tie-dye also known as shibori in Japan, Pelangi in Indonesia, Bandhani in India and Adire in West Africa, includes any technique in which fabric is gathered, folded, twisted, rolled, tied, stitched, or bound to resist the application of dye; It is one of the oldest and most-prevalent resists-dyeing techniques; Dyeing is such an ancient art; records indicate that it has been practiced throughout the world for more than six thousand years". ${ }^{17}$ In the Modern Textile Dictionary, tie-dye also known as a method of dyeing on the fabric by binding the fabric with fibers, rope or yarn to be dyed or colored. ${ }^{18}$

The tie-dye motif as a work of creativity and human activity in the dimension of intellectual property is protected in the form of copyright. As it is known that based on

\footnotetext{
${ }^{13}$ Soekanto, S. (2014). Pengantar Penelitian Hukum. Jakarta: Universitas Indonesia. p. 1-2.

14 Fajar, M., \& Achmad, Y. (2010). Dualisme Penelitian Hukum. Normatif dan Empiris, Yogyakarta: Pustaka Pelajar. p. 90.

15 Encyclopædia Britannica. Retrieved from: https://www.britannica.com/technology/tie-dyeing, accessed on August 7, 2020.

16 Ibid.

17 Simon-Alexander, S. (2013). Tie Dye: Dye it, wear it, Share it. New York: Potter Craft. p. 12-13.

18 Widodo, S. T. op. cit. p. 102.
} 
Law Number 28 of 2014 concerning Copyright (hereinafter UUHC), copyrighted works that are protected are works of art, literature, and science produced based on one's inspiration, ability, thinking, imagination, skills, and expertise. which is manifested in real form, namely works that can be seen, touched, or heard. ${ }^{19}$

In the copyright regime, a protection system for a creation/work is provided automatically based on the declarative principle after creation has become tangible. The concept of automatic protection is based on one of the principles in the Berne Convention for the Protection of Literary and Artistic Works, namely "automatically protection" or direct protection. In other words, a Creator does not need to take notes on his creation, because protection is immediately given as soon as a creation is manifested in an expression work. Based on this principle, recording of creation is not obligatory or facultatively. ${ }^{20}$ Bearing in mind that in producing a creation, a Creator carries out a process that is not short-lived and is even willing to sacrifice energy, thought, money and intellect to produce a creation that has economic value. Seeing the sacrifice of a Creator, Creation deserves protection in the form of the Creator's exclusive rights. This is consistent with John Locke's Labor Theory-Natural Right Theory and Robert M. Sherwood's IPR protection theory, namely reward theory and risk theory. ${ }^{21}$ Based on this theory, it is proper for a Creator to be given protection and appreciation for his efforts in producing a creation.

In the dimension of international law, protection of copyright is also regulated through the Agreement on Trade-Related Aspects of Intellectual Property Right (hereinafter TRIPs Agreement) and the Berne Convention. In accordance with the provisions in the TRIPs Agreement, Indonesia as one of the TRIPs Agreement member countries is obliged to harmonize regulatory standards regarding copyright protection in order to comply with the provisions in the TRIPs Agreement. ${ }^{22}$ Unfortunately, the TRIPs Agreement does not regulate the meaning of Copyright, this agreement only states that "copyright protection shall extend to expressions and not to ideas, procedures, methods of operation or mathematical concepts as such". ${ }^{23}$ Referring to this provision, copyright is protected when it has been expressed (work expression). In the TRIPs Agreement, it was determined that "related to copyright protection refers to the provisions of Article 9

\footnotetext{
${ }^{19}$ Article 1 number 1 of Law Number 28 Of 2014 Concerning Copyrights (UUHC).

20 Supasti, N. K. (2014). Relevansi Hak Kekayaan Intelektual dengan Hak Asasi Manusia Generasi Kedua. Jurnal Dinamika Hukum. 14(3). p. 525. DOI: http://dx.doi.org/10.20884/1.jdh.2014.14.3.323

21 Dharmawan, N. K.S. et. al. (2019). Protecting Balinese Culinary Innovation through Patent Law. International Journal of Innovation, Creativity and Change. 9(10). pp. 116-126. Retrieved from: https://www.ijicc.net/images/vol9iss10/91020_Dharmawan_2019_E_R.pdf, accessed on August 8, 2020.

22 Dharmawan, N. K. S. (2017). Protecting Traditional Balinese Weaving Trough Copyright Law: Is It Appropriate?. Diponegoro Law Review, 2(1), 57-84.

${ }^{23}$ Article 9 point 2 the Agreement on Trade-Related Aspect of Intellectual Property Right.
} 
Relation to the Berne Convention which basically states that Members shall comply with Article 1 through 21 of the Berne Convention and the Appendix". ${ }^{24}$

Furthermore, based on the provisions of Article 2 of the Berne Convention, it is determined that "the expression 'literary and artistic works' shall include every production in the literary, scientific, and artistic domain, whatever may be the mode of form of its expressions, such as books, pamphlets, and other writings; lectures, addresses, sermons, and other works of the same nature; dramatic or dramaco-musical works; choreographic works and entertainments in dumb show; musical compositions with or without music; cinematographic works to which are process analogous to cinematography; works of drawing, painting, architecture, sculpture, engraving, and lithography; photographic works to which are assimilated works expressed by a process analogous to photography; works of applied art; illustrations, maps, plans, sketches and three-dimensional works relative to geography, topography, architecture or science". ${ }^{25}$

In the provisions of Article 40 paragraph (1) letter q of the UUHC, it is emphasized that a work or copyrighted work that is protected is a copyrighted work with a distinctive form and shows originality. ${ }^{26}$ This is in accordance with the thoughts of Miller and Davis who emphasize the criteria of originality or purity as the basis for providing copyright protection.

In Indonesia, the tie-dye motif as an intellectual work is protected under the provisions of Article 40 letter $j$ of the UUHC, which essentially provides protection for works of art, literature, and science including batik art and other motive arts. ${ }^{27}$ Referring to the explanation of article 40 letter $j$ of the UUHC, it can be understood that "batik art" is a contemporary batik motif that is innovative and not traditional. ${ }^{28}$ The work is protected because it is considered to have artistic value, namely in the form of images, patterns, or color compositions. In the explanation of Article 40, letter $\mathrm{j}$ also explains "other motive artworks", namely the motifs of the Indonesian nation's wealth that can be found in various regions, including songket art, ikat motifs, ulos motifs, filter motifs or other nontraditional motifs, innovative and continues to be developed today. ${ }^{29}$ Batik artworks or other art motifs receive protection based on the copyright regime, which is valid for the life of the Creator and continues for 70 (seventy) years after the Creator's death as regulated in the provisions of Article 58 paragraph (1) UUHC. ${ }^{30}$

24 Ibid.

${ }^{25}$ Article 2 of the Berne Convention for the Protection of Literary and Artistic Works.

26 Dharmawan, N. K. S. dkk. (2018) Harmonisasi Hukum Kekayaan Intelektual Indonesia. Denpasar: Swasta Nulus.

${ }^{27}$ Article 40 UUHC.

${ }^{28}$ Penjelasan Article 40 UUHC.

29 Ibid.

${ }^{30}$ Article 58 clause (1) UUHC. 
Based on the description above, the tie-dye motif can be categorized as "other motif artwork" as stipulated in the provisions of Article 40 letter $j$ of the UUHC. Protection for the tie-dye motif is given considering that this motif is seen as the wealth of the Indonesian people that can be found in various regions and is contemporary, innovative and continues to be developed and has high economic value. Internationally, the tie-dye motif is also recognized as one of the objects of copyright protection considering the provisions of the TRIPs Agreement which provide copyright protection not on ideas or methods but on a creation in real form.

\section{B. Responsibilities of Influencer in Promoting Tie-Dye Motif Product According to Copyright Law}

Since 2019, tie-dye art has again become a trend in the world of fashion. The interest of local and international brands in the uniqueness of the patterns and colors in this motif cannot be denied. Various online shops are competing to sell clothing sets with this motif. In the current industrial revolution 4.0, developments in the world of trade have undergone many changes. One of the changes that have occurred is the use of social media as a marketing medium. Social media itself is often used by business people to build their image and market their products. ${ }^{31}$ business actors are now increasingly active in using endorsements and using influencer services to increase the sales of their goods and services. ${ }^{32,33}$

According to Cambridge Dictionary, Endorsement is also known as "a public statement, especially by someone who is famous, that the person uses or likes a particular product". ${ }^{34}$ Influencers can be defined as people or figures on social media with a large number of followers and have an influence amongst society. ${ }^{35}$ In conducting an endorsement, an influencer states that he uses or endorses a product.

These influencers promote a product in a fairly simple way, namely word of mouth or what is known as the Word of Mouth (WOM). ${ }^{36}$ Content created by influencers often presents itself using a particular product or brand in order to share the influencer's own

\footnotetext{
${ }^{31}$ European Commission. "Internet Advertising of Businesses - Statistics on Usage of Ads." Retrieved from: https://ec.europa.eu/eurostat/statistics-explained/index.php?title=Internet_advertising_of_businesses_statistics_on usage of ads, accessed on August 8, 2020.

${ }^{32}$ Riefa, C., \& Clausen, L. (2019). Towards Fairness in Digital Influencers' Marketing Practices. Available at SSRN: https://ssrn.com/abstract=3364251. p. 1

${ }^{33}$ Cooley, D., \& Parks-Yancy, R. (2019). The effect of social media on perceived information credibility and decision making. Journal of Internet Commerce, 18(3), 249-269. p. 253

$\begin{array}{llll}34 & \text { Cambridge } & \text { Dictionary. }\end{array}$ https://dictionary.cambridge.org/dictionary/english/endorsement, Accessed on August 8, 2020.

35 Asmara, T. T. P., Abubakar, L., \&Handayani, T. (2020). Digital Assets: The Idea of Indonesian Property Law Reform and Its Potential as a Collateral Object. Hasanuddin Law Review, 5(3), pp. $278-288$. DOI: http://dx.doi.org/10.20956/halrev.v5i3.1735

${ }^{36}$ Evelina, L. W., \&Handayani, F. (2018). Penggunaan Digital Influencer dalam Promosi Produk (Studi Kasus Akun Instagram @bylizzieparra). Warta Ikatan Sarjana Komunikasi Indonesia, 1(01), pp. 71-82. DOI: https://doi.org/10.25008/wartaiski.v1i01.10
} 
experiences and recommend it directly to their followers. ${ }^{37}$ According to Forbes, $92 \%$ of consumers trust advertising by influencers more than traditional advertising. ${ }^{38}$ One of the products that are often advertised by influencers today is clothes and various accessories with tie-dye motifs.

With regard to UUHC, influencers' actions that present themselves when using a product can be categorized as an Announcement. Referring to the provisions of Article 1 point 11 of the UUHC, all forms of action in the form of reading, broadcasting, exhibiting work in any way and any media so that the work can be read, heard or seen by others can be said to be an announcement of a creation. ${ }^{39}$

Referring to the provisions of Article 40 of the UUHC, it can be argued that the scope of rights owned by the Creator or Copyright Holder to a copyrighted work is the right to announce his creation, duplicate or reproduce his work, the right to get legal protection, and the right to grant permission or prohibit other people who without his permission or approval, he has undertaken an act of announcing, reproducing, and even renting his creation for commercial purposes. ${ }^{40}$ However, to obtain copyright legal protection for a work, an author must be able to create a copyrighted work that has a distinctive form and shows originality. ${ }^{41} \mathrm{~A}$ product will not receive copyright protection if it does not have a unique shape or cannot show originality. According to Ari Juliano Gema, Deputy of IPR and Regulation of BEKraf, copyright provides protection for paintings, patterns and motifs. ${ }^{42}$ With regard to the protection of tie-dye motifs, a clothing manufacturer can be categorized as violating copyright if there is a similarity in the motifs of part or all of its products, such as the same color, shape, or material or material.

Influencers who advertise clothing or accessories with tie-dye motifs should pay attention to the shape and originality of the advertised product. This is in accordance with the provisions in Article 10 of the UUHC which in essence determines that every person who manages a trading place is prohibited from selling and duplicating goods resulting from violations of copyright and/or related rights in the place they manage. ${ }^{43}$ Referring to the provisions of Article 10 of the UUHC, influencers can be interpreted as people who manage a trading place. Assuming that the influencer is the person who manages the

${ }^{37}$ Riefa, C., \& Clausen, L. Op. cit. pp. 1-2

38 Fertik, M. (2020). "Why is Influencer Marketing Such a Big Deal Right Now?" Retrieved from: https://www.forbes.com/sites/michaelfertik/2020/07/02/why-is-influencer-marketing-such-a-big-deal-rightnow/\#486dc26a75f3, accessed on August 8, 2020.

${ }^{39}$ Article 1 clause 11 UUHC.

${ }^{40}$ Dharmawan, N. K. S. et.al. Op. cit. h. 24.

41 Ibid. p. 22.

42 Tobing, L. "Pelanggaran Hak Cipta Terhadap Ciptaan yang Belum Didaftarkan." Retrieved from: https://www.hukumonline.com/klinik/detail/ulasan/t561be135c587a/pelanggaran-hak-cipta-terhadap-ciptaanyang-belum-didaftarkan/, accessed on August 8, 2020.

${ }^{43}$ Article 10 UUHC. 
place of commerce, influencers are not allowed to sell goods that are the result of copyright infringement.

In the context of copyright, the actions of the influencer can be categorized as an indirect infringement. Indirect violation is a form of violation committed by facilitating and supporting the occurrence of a violation with a benchmark that focuses on the condition of the offender who knows or should know that an item related to him is the result of duplication which is a violation. ${ }^{44}$ Based on the provisions of Article 114 of the UUHC, it can be understood that if an influencer as a manager of a trading place knows and deliberately sells goods resulting from copyright infringement as regulated in the provisions of Article 10, he or she can be punished with a maximum fine of Rp. 100,000,000.00 (one hundred million rupiah). ${ }^{45}$

Referring to the provisions in Article 95 paragraph (1) of the UUHC, all disputes regarding Copyright can be resolved through mediation, negotiation, conciliation, arbitration, or through litigation or court, in this case, the Commercial Court. ${ }^{46}$ In accordance with the provisions of Article 95 paragraph (4) it is also determined that in addition to violations in the form of Piracy, if the disputing parties are known to exist or are in Indonesia, then copyright infringement disputes can be resolved by means of mediation before criminal charges are made. 47

In Article 96 paragraph (1) of the UUHC, it is determined that a party who has suffered a loss of economic rights is entitled to compensation. ${ }^{48}$ Compensation is given and included at once in the court's decision regarding criminal cases of Copyright and / or Related Rights, as regulated in the provisions of Article 96 paragraph (1) of the UUHC. 49 The compensation is given to the creator, copyright holder, related rights holders or their heirs. Regarding the period of payment of compensation, it can be paid no later than 6 (six) months after the court decision has permanent legal force or is also known as inkracht van gewijsde..$^{50}$

Seeing this phenomenon, it is important for an influencer to look at all the products offered by business actors who wish to use their services in the form of endorsements. An influencer who will promote a product must know everything related to the product that will be promoted to prevent inconvenience in the future as a result of legal claims for

${ }^{44} \mathrm{He}, \mathrm{H}$. (2019). Research on the Relationship Between Digital Music Copyright Infringement Theory and Interest Balance Theory. In The 4th International Conference on Economy, Judicature, Administration and Humanitarian Projects (JAHP 2019) (pp. 226-229). Atlantis Press. DOI: https://doi.org/10.2991/jahp-19.2019.49

${ }^{45}$ Article 114 UUHC.

${ }^{46}$ Article 95 clause (1) dan Clause (2) UUHC.

${ }^{47}$ Article 95 clause (4) UUHC.

${ }^{48}$ Article 96 Clause (1) UUHC.

${ }^{49}$ Article 96 Clause (2) UUHC.

50 Widyastutiningrum, D. A. (2019). Perlindungan Hukum Terhadap Hak Cipta Batik Motif Ceplok Segoro Amarto Di Kota Yogyakarta. JIPRO: Journal of Intellectual Property, 2(1). 
copyright infringement. If an influencer is proven to knowingly or knowingly sell, market or promote a product which is the result of copyright infringement, then the influencer can be prosecuted and sentenced to a fine in accordance with the provisions of the applicable laws and regulations. For parties who have suffered a loss of economic rights, they can file a claim for compensation. Regarding disputes over copyright, it can be resolved through mediation, negotiation, conciliation, arbitration or by filing a lawsuit at the court, namely the Commercial Court.

\section{CONCLUSION}

The tie-dye motif is protected as an object of copyright protection based on the provisions of Article 40 of the UUHC, namely "works of art with other motives". Protection for this tie-dye motif is given considering that this motif is one of the nation's assets that can still be found in various regions in Indonesia and is contemporary, innovative, and continues to be developed and has high economic value. Promotion or endorsement by an influencer can be interpreted as Announcement. In announcing a copyright work/creation, the elements of uniqueness and originality are important points in copyright protection, so it is only natural for an influencer to prevent the sale or duplication of goods resulting from violations of Copyright and/or Related Rights. If an influencer is proven intentionally and knows there are indications of copyright infringement on creation, but the influencer allows the act, then it can be categorized as indirect infringement so that it can be sued to provide compensation by the party who has suffered a loss of economic rights in accordance with the provisions in statutory regulations. Such influencers can also be sentenced to a maximum fine of $\mathrm{Rp}$. $100,000,000.00$ (one hundred million rupiah). Thus, it is important for influencers to look at all information about the products offered by business actors to them before they agree to do the endorsement.

\section{REFERENCE}

Agreement on Trade-Related Aspect of Intellectual Property Right.

Berne Convention for the Protection of Literary and Artistic Works.

Cooley, D., \& Parks-Yancy, R. (2019). The effect of social media on perceived information credibility and decision making. Journal of Internet Commerce, 18(3), pp. 249-269

Dharmawan, N. K. S. (2017). Protecting Traditional Balinese Weaving Trough Copyright Law: Is It Appropriate?. Diponegoro Law Review, 2(1), 57-84. 
Dharmawan, N. K. S. et.al. (2018) Harmonisasi Hukum Kekayaan Intelektual Indonesia. Denpasar: Swasta Nulus.

Dharmawan, N. K.S. dkk. (2019). Protecting Balinese Culinary Innovation through Patent Law. International Journal of Innovation, Creativity and Change. 9(10). pp. 116126. Retrieved from: https://www.ijicc.net/images/vol9iss10/91020_Dharmawan_2019_E_R.pdf, diakses pada 8 Agustus 2020.

Dianawati, V. Fimela Historia: Seni Tekstil Tie-Dye yang Diprediksi Jadi Tren di Tahun 2020. Retrieved from: https://www.fimela.com/beauty-health/read/3862121/fimelahistoria-seni-tekstil-tie-dye-yang-diprediksi-jadi-tren-di-tahun-2019, accessed on 7 August 2020.

European Commision. Internet Advertising of Businesses - Statistics on Usage of Ads. Retrived from: https://ec.europa.eu/eurostat/statisticsexplained/index.php?title=Internet_advertising_of_businesses__statistics_on_usage_of_ads, accessed on 8 August 2020

Evelina, L. W., \&Handayani, F. (2018). Penggunaan Digital Influencer dalam Promosi Produk (Studi Kasus Akun Instagram @bylizzieparra). Warta Ikatan Sarjana Komunikasi Indonesia, 1(01), pp. 71-82. DOI: https://doi.org/10.25008/wartaiski.v1i01.10

Fajar, M., \& Achmad, Y. (2010). Dualisme Penelitian Hukum. Normatif dan Empiris, Yogyakarta: Pustaka Pelajar.

Fertik, M. (2020) Why is Influencer Marketing Such a Big Deal Right Now? Retrieved from: https://www.forbes.com/sites/michaelfertik/2020/07/02/why-is-influencermarketing-such-a-big-deal-right-now/\#486dc26a75f3, accessed on 8 August 2020.

Halls, J., \& Martino, A. (2018). Cloth, copyright, and cultural exchange: textile designs for export to Africa at the National Archives of the UK. Journal of Design History, 31(3), pp. 236-254.

Haryanto, H. (2020). Penerapan Transformasi Perpustakaan Berbasis Inklusi Sosial Di Perguruan Tinggi Melalui Literasi Kewirausahaan Dan Entrepreneur Corner : Studi Pada Perpustakaan Universitas Sebelas Maret. Jurnal Ipi (Ikatan Pustakawan Indonesia), 5(1), pp. 217-224. https://doi.org/10.1234/jurnal ipi.v5i1.4

He, H. (2019). Research on the Relationship Between Digital Music Copyright Infringement Theory and Interest Balance Theory. In The 4th International 
Conference on Economy, Judicature, Administration and Humanitarian Projects (JAHP 2019) (pp. 226-229). Atlantis Press. https://doi.org/10.2991/jahp19.2019.49.

Mahartha, A. (2018). Pengalihwujudan Karya Sinematografi Menjadi Video Parodi Dengan Tujuan Komersial Perspektif Perlindungan Hak Cipta. Kertha Patrika, 40(01), pp. 13-23. Doi:10.24843/Kp.2018.V40.I01.P02

Mustika, A. (2018). Perlindungan Hak Cipta atas Motif Batik Buketan sebagai Warisan Budaya di Pekalongan (Studi Terhadap Karya Seni Batik Tradisional Pekalongan). Notarius, 11(2), pp. 146-163. https://doi.org/10.14710/nts.v11i2.23460

Nakamura, R., Tanaka, Y., Ogata, A., \& Masakazu, N. (2014). Scientific evidence by fluorescence spectrometry for safflower red on ancient Japanese textiles stored in the Shosoin Treasure House repository. Studies in Conservation, 59(6), pp. 367376. https://doi.org/10.1179/2047058413Y.0000000082

Ramadhania, N. (2018). Tie-Dye Peluang Bisnis Baru melalui Tren Fashion 2018. Retrieved from: https://www.kompasiana.com/nurramadhania1456/5b115451dd0fa852d10566a2/ti e-dye-peluang-bisnis-baru-melalui-tren-fashion-2018?page=all, accessed on 7 August 2020.

Riefa, C., \& Clausen, L. Towards Fairness in Digital Influencers' Marketing Practices. Available at SSRN: https://ssrn.com/abstract=3364251. p. 1

Ristiani, S., 2016. Pengembangan Teknik Tritik Jumputan Dengan Sistem Lipat Ikat Dan Lipat Jelujur. Dinamika Kerajinan Dan Batik, 33(1), pp. 9-24. Doi: http://dx.doi.org/10.22322/dkb.v33i1.1102.

Simon-Alexander, (2013). S.Tie Dye: Dye it, Wear it, Share it. New York: Potter Craft, 2013.

Soekanto, S. (2014). Pengantar Penelitian Hukum. Jakarta: Universitas Indonesia.

Supasti, N. K. (2014). Relevansi Hak Kekayaan Intelektual dengan Hak Asasi Manusia Generasi Kedua. Jurnal Dinamika Hukum. 14(3). p. 525. DOI: http://dx.doi.org/10.20884/1.jdh.2014.14.3.323

Tobing, L. (2015). Pelanggaran Hak Cipta Terhadap Ciptaan yang Belum Didaftarkan. Retrieved from: 
Volume 3. Issue 2. December 2020 : 167 - 179

https://www.hukumonline.com/klinik/detail/ulasan/t561be135c587a/pelanggaranhak-cipta-terhadap-ciptaan-yang-belum-didaftarkan/, accessed on 8 August 2020

Undang-Undang Nomor 28 Tahun 2014 tentang Hak Cipta (Lembaran Negara Republik Indonesia Tahun 2014 Nomor 266, Tambahan Lembaran Negara Republik Indonesia Tahun 2014 Nomor 5599)

Warman, S. 6 Brand Lokal Keluarkan Motif Tie Dye UntukTampil Stylish. Retrived from: https://www.herworld.co.id/article/2020/7/14657-6-brand-lokal-keluarkan-motif-tiedye-untuk-tampil-stylish, accessed on 7 August 2020.

Widyastutiningrum, D. A. (2019). Perlindungan Hukum Terhadap Hak Cipta Batik Motif Ceplok Segoro Amarto Di Kota Yogyakarta. JIPRO: Journal of Intellectual Property, 2(1).

Yori Pratana, P., Supasti Dharmawan, N., \& Sri Indrawati, A. (2017). Pelaksanaan Ketentuan Hukum Terhadap Motif Kain Endek Berdasarkan Undang-Undang Nomor 28 Tahun 2014 Tentang Hak Cipta Di Kabupaten Gianyar. Kertha Semaya : Journal Ilmu Hukum. 